\title{
A framework for economic resilience assessment of agricultural production systems
}

\author{
Hassani, Leila; Kakhki, Mahmoud Daneshvar; Sabouni, Mahmoud Sabuhi; Fantke, Peter
}

Published in:

The Economics of Agriculture and Natural Resources

Link to article, DOI:

10.1007/978-981-15-5250-2_3

Publication date:

2020

Document Version

Peer reviewed version

Link back to DTU Orbit

Citation (APA):

Hassani, L., Kakhki, M. D., Sabouni, M. S., \& Fantke, P. (2020). A framework for economic resilience assessment of agricultural production systems. In The Economics of Agriculture and Natural Resources (pp. 2130). Springer. https://doi.org/10.1007/978-981-15-5250-2_3

\section{General rights}

Copyright and moral rights for the publications made accessible in the public portal are retained by the authors and/or other copyright owners and it is a condition of accessing publications that users recognise and abide by the legal requirements associated with these rights.

- Users may download and print one copy of any publication from the public portal for the purpose of private study or research.

- You may not further distribute the material or use it for any profit-making activity or commercial gain

- You may freely distribute the URL identifying the publication in the public portal 


\title{
A Framework for Economic Resilience Assessment of Agricultural Production Systems
}

\author{
Leila Hassani ${ }^{1,}$, Mahmoud Daneshvar kakhki ${ }^{2}$, Mahmoud Sabuhi sabouni ${ }^{3}$, Peter Fantke ${ }^{4}$ \\ ${ }^{1}$ Department of Agricultural Economics, Faculty of Agriculture, Ferdowsi University of Mashhad, \\ Iran \\ Expert of Export Promotion Bureau, Ministry of Agriculture - Jihad, Tehran, Iran \\ Email: leila.hassani@mail.um.ac.ir \\ ${ }^{2}$ Department of Agricultural Economics, Faculty of Agriculture, Ferdowsi University of Mashhad, \\ Iran, Email: daneshvar@um.ac.ir \\ ${ }^{3}$ Department of Agricultural Economics, Faculty of Agriculture, Ferdowsi University of Mashhad, \\ Iran, Email: Sabouhi@um.ac.ir \\ ${ }^{4}$ Division for Quantitative Sustainability Assessment, Department of Management Engineering, \\ Technical University of Denmark, Denmark, Email: pefan@dtu.dk \\ "Corresponding Author
}

\begin{abstract}
This study tries to evaluate economic resilience and sustainability in industrial dairy cattle farms. Resilience explains how well production systems withstand or rebound from aberration. This includes preserving, and restoring agricultural systems under threats that impact national economic development. A dairy farm is a type of agricultural system, production quality and profitability of them are a dominant feature of the economic resilience. These features are used in a multi-indicator modeling approach to assess the economic resilience of 30 dairy farms in Khorasan Razavi Province (Iran). Total revenue and total cost across all farms are $5.18 \times 10^{09}$ IRR, and $2 \times 10^{09}$ IRR per day, respectively. The average milk quality is 0.52 , which indicates the low-level milk quality. To evaluate the economic resilience indicator (ERI) for dairy farms, we developed an economic resilience indicator using profitability and milk quality which are normalized between zero and one. The economic resilience indicator was obtained using the arithmetic mean. The proposed indicator across all farms is about 0.49 , meaning that dairy farms are at the low-level. Hence, to increase the economic resilience of dairy farms, it is essential to improve the revenue and production quality of these units while reducing the total cost.
\end{abstract}

\section{JEL Classification: Q01, L51, M11, 010.}

Keywords: Economic Resilience Indicator, Quality factors in milk, Dairy farms profitability, Arithmetic mean, Dairy farms, Iran.

\section{Introduction}

Production is a vital requirement for national economic development. In the production process, a set of inputs is converted to outputs. Nevertheless, the transformation process implicates the generation of emissions, inefficient use of available resources, etc.(Galal \& Moneim, 2015). Therefore, a production system will have asustained production that is resistant to shocks and hazards (Fiksel, 2006). Such system is resilient when it can anticipate 
and prevent disasters and recover them in a timely (www.fao.org). A resilient economic system is a system that makes effective use of the remaining resources at any given time (Rose, 2015). Economic resilience is obtained at three levels of microeconomics, mesoeconomics, and macroeconomics. Microeconomic and Macroeconomic levels are related to individual business and the combination of all economic entities. At the Mesoeconomics level, resilience can reinforce an industry or market, for instance, innovative pricing mechanisms (Rose, 2015).

A Dairy farm is a type of agricultural systems that has an essential role in societies, providing sources of protein, fertilizer, fuel, etc. Dairy production and impact on natural resources is a dominant feature of livestock for resilience (Naylor, 2009). Livestock products not only illustrate a source of high-quality food, but they are an original of revenue for many small farmers in developing countries (www.fao.org). Dairy cattle are fostered to produce milk; hence, milk quality control is an important part of the milk processing industry for all of the scales (small, medium, and large scale). To produce healthy dairy products, raw materials should have good quality. Hence, quality control must begin at the farm. This is achieved through approved methods of milk production. On the other hand, the advancement of technology and the improvement of productivity in dairy farms is one of the most important factors in economic growth and development in Iran over the last few decades. In the coming years, milk production costs will increase dramatically. In the field of global competition in production, countries, and industries will be more successful in finding ways to prevent economic loss (Qobadi. M, 2015). Apeldoorn et al (2011) studied the resilience of agricultural systems based on Dutch dairy farms and found system models are beneficial. These models recognize destabilizing and stabilizing forces, the changeable variables, and thresholds that assign the resilience of a system (van Apeldoorn, Kok, Sonneveld, \& Veldkamp, 2011). So far, a significant economic resilience indicator is not presented. In most previous studies, the economic resilience indicator is based on guess, assumption, and integration of several variables that are affecting economic resilience. Béné (2013) defined and presented the economic resilience indicator as a resilience cost (Béné, 2013). Briguglio et al (2006) expanded the resilience economic index. They considered macroeconomic stability, microeconomic market efficiency, good governance, and social development as a sub-indicators of economic resilience. They evaluated the economic resilience index using the arithmetic mean of those sub-indicators (Briguglio, Cordina, Farrugia, \& Vella, 2006). Darnhofer (2014) assessed the concept of farm management resilience in the face of climate change and economic uncertainty. He illustrated that farm resilience can be augmented or 
expunged by policy measures and showed how farmers balance the short-term efficiency and the long-term transformability (Darnhofer, 2014). Glover (2012) evaluated the resilience of dairy farmers in the UK coping with foot-and-mouth disease (Glover, 2012); the resilience of farms in Australia in the face of protracted drought was studied by Sysak (2013)(Sysak, 2013). Kenny (2011) (Kenny, 2011) examined how to deal with climate change in New Zealand. Darnhofer (2010) studied the strategies of Austrian family farmers to build resilience (Darnhofer, 2010). Astigarraga et al (2011) tested how French beef farmers maintain their resilience in the face of market variations and climatic fluctuations (Astigarraga \& Ingrand, 2011). In most of these studies, only one feature that would cause resilience was considered. Hassani et al (2018) measured the energy and environmental aspects of Iranian dairy farms based on optimal nutrition and mathematical programming (Hassani et al, 2018). In another study, they also defined a resilience and sustainability indicator for dairy farms and optimized this indicator by expanding the mathematical programming and metaheuristic algorithms (Hassani et al, 2019).

However, in the study of Hassani et al. (2019), several pillars of sustainability and resilience were integrated. Still, the effect of each pillar lonely, and its comparison with aggregation was not examined. Thus, based on the existing published literature, studies focusing on the economic resilience assessment of industrial dairy farms according to economic resilience indicators have not been carried out in Iran. Therefore, it is the aim of the present study to evaluate the economic resilience of dairy farms in Khorasan Razavi province of Iran based on profitability and milk quality indicators, which are some sub-indicators of economic resilience. In sum, the study aims to evaluate the economic resilience of dairy farms based on quality factors and profitability. The results of this study would help the farmers to be more resilience by modifying milk quality and cost.

The rest of the chapter is structured as follows. Section 2 introduces the methodology and the general structure of the model. Section 3 presents the main results of the study, and the final section provides a summary and concluding remarks.

\section{Methodology}

Khorasan Razavi province is the fourth largest province in Iran and is located in the east north of Iran. (Anonymous, 2015). Data used in this study were collected from 30 dairy farms through questionnaires and interviews during 2016 based on non-random sampling. In this non-random sampling method, farms are selected based on the researcher's opinion. In this study, to determine the economic resilience indicator, dairy farms were evaluated in 
terms of data for quality factors in milk production and profitability. The quality factors and profitability of each farm are calculated by considering their criteria, which are given in table 1.

Insert table 1 about here

The Somatic Cell Count (SCC) is the main indicator of milk quality. The majority of them are leukocytes (white blood cells) sent to fight the udder infection. Therefore the milk from cows that have mastitis has more somatic cells. The Somatic Cell Count is quantified by the number of cells per milliliter of milk. In general terms, the standard of SCC is 100000 or less and illustrates an 'uninfected' cow. The threshold of SCC is 200,000 and would determine whether a cow is infected with mastitis, and the result of greater than 300,000 shows the cow is infected (Schukken, Wilson, Welcome, Garrison-Tikofsky, \& Gonzalez, 2003).

Bacterial contamination of milk can usually occur after secreted the milk into the udder by three main sources including outside the udder, within the udder, and from the equipment used for milk handling and storage (Wallace, 2009). The microbial load is quantified by colony-forming units per milliliter $(\mathrm{CFU} / \mathrm{ml})$ of milk. High bacteria counts (more than 10,000 $\mathrm{CFU} / \mathrm{ml}$ or more than 100000 bacteria per milliliter) suggest that bacteria are entering milk from a variety of possible sources (Nádia, Diane, Débora, \& Mirlei, 2012).

Aflatoxins are the major concern to the dairy industry because they are naturally produced by the fungi and Most frequently, are found in livestock feed, including corn silage, maize, and cotton seeds. Aflatoxin M1 has a high transfer rate to livestock products such as milk. Fresh milk is continually monitored for aflatoxin M1; if concentrations of M1 is $0.5 \mathrm{mg} / \mathrm{kg}$ in the US or more than $0.05 \mathrm{mg} / \mathrm{kg}$ in the EU, are considered unacceptable and are not used for products that enter the human food chain. In general, based on Food and Drug Administration (FDA), the level of aflatoxin M1 in milk is $0.5 \mathrm{ppb}$ (parts per billion), and such milk is acceptable (Iqbal, Jinap, Pirouz, \& Faizal, 2015).

Antibiotics are used to treat cows with mastitis infections, and such cows may have antibiotic residues in their milk. Therefore, these kinds of milk are either discarded or gathered into a separate tanks and are not used for human consumption. Therefore, based on the FDA's standard, it is essential, no antibiotics to be detected on milk while analyzing it (Food \& Administration, 2009).

More than a decade, the management of product quality has supposed novel strategic importance, giving consumers the right to choose and buy high-quality products at reasonable prices. On the other hand, the quality of production is one of the effective factors in producer 
support estimate (PSE) by governments (Morgan \& Piercy, 1998). Therefore, considering these quality factors as a sub-indicators of economic resilience indicator seems to be necessary simultaneously with increased profitability in dairy farms.

To calculate microbial load, aflatoxin, antibiotic, and Somatic Cell Count (SCC) indicators, the amount of each factor across all farms considered based on milk testing and quality control. Then we extended the quality indicator for all of them, which are given in equation 1 to 4 .

The difference between the revenue obtained from product sale and the opportunity cost of the inputs is economic profit (Von Mises, 2008). Hence, profitability is the ability of a producer to get profit (Park \& Irwin, 2004). There are several different ways to measure the profitability of farms. In this study, we focus on profitability ratios of dairy farms, which are measured by dividing total expenditure to total revenue (equation 5). Next, the economic resilience indicator is developed based on all aspects of the research, includes four factors of milk quality and farm profitability.

$$
\begin{aligned}
I_{S C C} & =\frac{\text { The standard amount of SCC in milk }(1000 \text { cell per milliliter })}{\text { Total amount of SCC in milk across all farms }(1000 \text { cell per millititer })} \\
I_{M C} & =\frac{\text { The standard amount of } M C \text { in milk }(\mathrm{CFU} / \mathrm{ml})}{\text { Total amount of } M C \text { in milk across all farms }(\mathrm{CFU} / \mathrm{ml})} \\
I_{A F} & =\frac{\text { The standard amount of Aflatoxin in milk }(\mathrm{ppb})}{\text { Total amount of Aflatoxin in milk across all farms }(\mathrm{ppb})} \\
I_{A N} & =\frac{\text { The standard amount of Antibiotic in milk }(\mathrm{mg} / \mathrm{kg})}{\text { Total amount of Antibiotic in milk across all farms }(\mathrm{mg} / \mathrm{kg})} \\
I_{\text {Profit }} & =\frac{\text { Total Cost }(\mathrm{IRR})}{\text { Total Revenue }(\mathrm{IRR})}
\end{aligned}
$$

Where $I_{S C C}, I_{M C}, I_{A F}, I_{A N}$, and $I_{\text {Profit }}$ are Somatic Cell Count indicator, Microbial load indicator, Aflatoxin indicator, Antibiotic indicator, and profitability indicators, respectively. In this research, labor and farm manager salary, feed cost, fuel cost, sperm, and inoculation are considered as the total cost. Total revenue is obtained by the sale of products such as milk, calf, manure, and meat. All five indicators as a sub-indicators of economic resilience and will be between zero and one. As the result closes to 1, it shows that the system is resilient. Finally, the economic resilience indicator is obtained using the arithmetic mean.

\section{Results and Discussion}

The current quality and profitability of the dairy farms were calculated via data extracted from the questionnaires and interviews which is shown in Table 2. The results show that the total Somatic Cell Count in milk for all dairy farms is on average 269,500 Cells per ML. This 
means that more than half of the cows in our study are infected by mastitis. On the other hand, SCC monitoring is important for dairy producers because a lower SCC indicates highgrade animal health. If the number of somatic cells rises, milk yield is likely to fall or has poor quality or even leads to unsaleable milk. Such milk is inappropriate for human consumption. The same as SCC, total microbial load, and aflatoxin in milk across all farms are 283,000 bacterial per $\mathrm{ml}$ and 224 ppb, respectively which highlights low milk quality in the region. In addition to SCC, the microbial load is also obtained from cows with mastitis. Increased microbial load in raw milk has consequences including fat, protein and milk glucose corruption, the reduced production efficiency of dairy products such as cheese and yogurt, etc. As well as mycotoxin in livestock feed led to animal productivity reduction and contamination of cattle products such as milk, meat, etc., Aflatoxins is a kind of toxins that causes the economic losses in this area. Aflatoxin B1 is the most strong of the aflatoxin group. It has a carcinogen factor, and aflatoxin M1 is a product of aflatoxin B1 and appears in the milk of lactating cows (Iqbal et al., 2015). Based on the FDA's regulate the level of aflatoxin in milk is $0.5 \mathrm{ppb}$; However, in our study is obtained $224 \mathrm{ppb}$ and indicates the detection is necessary. Also, the control of aflatoxin should be expanded seriously in this field because is costly for human and animal health. According to table 2, $15 \mathrm{mg} / \mathrm{ml}$ antibiotic detected across all farms, and it seems logical because antibiotics are used to treat cows with mastitis infections. According to our results, highly likely half of the cows in dairy farms of this region have mastitis.

Due to the low level of production quality, 0.52, as expected these dairy farms have the lowest profitability. According to the results, the profitability ratio across all farms is 0.46 . The profitability of a production unit is related to production costs. In dairy farms, $60-70 \%$ of the costs are related to animal feed. Therefore, it is essential to manage economical and highquality livestock feeding in dairy farms. It should be noted that quality factors of milk, as well as profitability of each dairy farm are calculated individually. The results indicated that 6 dairy farms (20\%), 2 dairy farms (6.7\%), 4 dairy farms (13.3\%), 2 dairy farms $(6.7 \%)$ and 15 dairy farms (50\%) from 30 dairy farms under study have a middle-level of profitability, Somatic Cell Count in milk, Microbial load in milk, Aflatoxin in milk, and Antibiotics in milk, respectively. However, it does not imply these farms are at the level of economic resilience because by assessing the average of quality and profitability indicators or economic resilience indicator for each farm, it was observed that none of them are at the resilient level.

Insert table 2 about here 
Then, after calculating the quality factors, profitability indicators and examining the current state of dairy farms, economic resilience indicators are obtained. Economic resilience indicator (ERI) through the arithmetic mean of the sub-indicators is calculated as:

$E R I=\frac{I_{S C C}+I_{M C}+I_{A F}+I_{A N}+I_{\text {Profit }}}{5}$

Compensating errors reduced due to the linearity of equation 6 and average in separate steps in the calculation process. (Chaves \& Alipaz, 2007). The economic resilience indicator is obtained at three levels (scale from zero to one) according to Table 3.

Insert table 3 about here

Overall, the economic resilience indicator across all sub-indicators is 0.49 , indicating that dairy farms in this study have low-level economic resilience. This result is in line with the results of the studies by Hassani et al. (2018 and 2019). Previous studies investigated, compared and determined the economic resilience of industrial dairy cattle units, using the cost, microeconomic market efficiency, policy measurement, and cattle diseases. However, in some of these studies, only the cost of milk production were estimated, but most of these studies did not provide any solution to reduce the overall cost in dairy farms. Hassani et al (2019) assessed the resilience and sustainability indicator in the field of all dimensions. They concluded that if all the components of sustainability and resilience are considered together, it is possible to achieve a high-performance production system. In line with our results, by considering per unit of inputs used, total cost, revenue, and quality factors of milk production can be achieved. For instance, how much output is produced? Then combine all aspects in the final model to arrive at a solution that can effectively be recommended to farmers. Thereby, an input unit is efficient when its production rate is the same as its consumption. To improve the economic resilience indicator, in addition to profitability and milk quality, it is suggested that other factors affecting the process of improving economic resilience to be identified, evaluated and introduced in the overall determination of economic resilience indicator. For instance, the policy of producer support estimates (PSE) is one of the most important factors in this regard in Iran. Milk demand function, the risk or uncertainty and set prices accordingly are other factors that can be additionally considered in the assessment of economic resilience and sustainability in dairy farms. Reviewing each goal should be based on its priority, also can be effective in changing the units. In this regard, it is recommended to use a weighted 
geometric mean. In the present study, as well as previous studies, all data have been conducted on the basis of cross-sectional data. Therefore, in addition to the above mentioned, it is recommended to use the dynamic method.

\section{Conclusions and policy recommendations}

This study was accomplished in Khorasan Razavi province of Iran to assess the economic resilience indicator based on milk quality and profitability in industrial dairy farms. Based on the results, quality factors including Somatic Cell Count, Microbial load, Aflatoxin, and Antibiotic in milk are very high, especially Aflatoxin. The limited attention and supervision to the quality of animal feed, animal health, and animal sanitation is one of the main reasons of economic losses in dairy farms, which in the long term leads to the elimination of farms. According to our findings, economic restraint in dairy farms will be achieved through threepoint: First, to concentrates on animal health and sanitation, Second, the quality of milk production, and based on these aspects, the resilience of economic in dairy farms will reach the global standard. It means the amount of Somatic Cell Count, Microbial load, Aflatoxin, and Antibiotics in milk should be under the FDA regulates. Finally, implementing encouraging policies to support the producers. For instance, setting the price of dairy products (milk, yogurt, cheese, etc.) should be based on their quality. In this approach, the producers are encouraged to produce a higher quality product to achieve greater profitability, and the consumer through having the right to choose goods can guarantee his/her health. Therefore, appropriate management of holding encourages plans can be effective in achieving economic resilience. To achieve the optimum result of a resilient economy, increasing animal health must be considered, and thereafter, we will see increased production performance, profitability, and economic resilience in industrial dairy farms.

\section{References}

Anonymous (2015) Annual agricultural statistics. Retrieved from http://www.koaj.ir ( in persian).

Astigarraga L, Ingrand S (2011) Production flexibility in extensive beef farming systems. Ecology and Society. 16(1).

Béné C (2013) Towards a quantifiable measure of resilience. IDS Working Papers. 2013(434), 1-27.

Briguglio L, Cordina G, Farrugia N, Vella S (2006) Conceptualizing and measuring economic resilience. Building the Economic Resilience of Small States, Malta: Islands and Small States Institute of the University of Malta and London: Commonwealth Secretariat. 265-288.

Chaves H. M., Alipaz S (2007) An integrated indicator based on basin hydrology, environment, life, and policy: the watershed sustainability index. Water Resources Management. 21(5), 883895.

Darnhofer I. (2010) Strategies of family farms to strengthen their resilience. Environmental policy and governance. 20(4), 212-222. 
Darnhofer I (2014) Resilience and why it matters for farm management. European Review of Agricultural Economics. 41(3), 461-484.

Fiksel J (2006) Sustainability and resilience: toward a systems approach. Sustainability: Science, Practice, Policy. 2(2).

Food U, Administration D (2009) Grade “A”"pasteurized milk ordinance. US Food and Drug Administration, Washington, DC, 52.

Galal N. M., Moneim A. F. A. (2015) A mathematical programming approach to the optimal sustainable product mix for the process industry. Sustainability. 7(10), 13085-13103.

Glover J. (2012) Rural resilience through continued learning and innovation. Local Economy. 27(4), 355-372.

Iqbal S. Z., Jinap S, Pirouz A, Faizal, A. A. (2015) Aflatoxin M 1 in milk and dairy products, occurrence and recent challenges: A review. Trends in Food Science and Technology. 46(1), $110-119$.

Kenny G. (2011) Adaptation in agriculture: lessons for resilience from eastern regions of New Zealand. Climatic Change. 106(3), 441-462.

Morgan N. A., Piercy, N. F. (1998) Interactions between marketing and quality at the SBU level: influences and outcomes. Journal of the Academy of Marketing Science. 26(3), 190-208.

Nádia M., Diane S., Débora O., Mirlei R. E. (2012) Evaluation of Microbiological quality of Raw Milk produced at two properties in the Far West of Santa Catarina, Brasil. Food and Public Health. 2(3), 79-84.

Naylor R. L. (2009) Managing food production systems for resilience Principles of Ecosystem Stewardship (pp. 259-280): Springer.

Park C.-H., Irwin S. H. (2004) The profitability of technical analysis: A review.

Qobadi M, M. D. Shahrami. A. (2015) Evaluation of Energy Indices in Qazvin Dairy Farms using Data Envelopment Analysis. Biomedical Engineering Journal. 4(4), 16.

Rose A (2015) Measuring Economic Resilience: Recent Advances and Future Priorities.

Schukken Y. H., Wilson D. J., Welcome F., Garrison-Tikofsky L., Gonzalez R. N. (2003). Monitoring udder health and milk quality using somatic cell counts. Veterinary research. 34(5), 579-596.

Sysak T. S. (2013) Drought, power and change: using Bourdieu to explore resilience and networks in two northern Victoria farming communities: University of Melbourne, Department of Resource Management and Geography.

van Apeldoorn D., Kok K., Sonneveld M., Veldkamp T (2011) Panarchy rules: rethinking resilience of agroecosystems, evidence from Dutch dairy-farming. Ecology and Society. 16(1).

Von Mises L (2008) Profit and loss: Ludwig von Mises Institute.

Wallace R. L. (2009) Bacteria counts in raw milk. Dairy Cattle. Management, 1-4.

www.fao.org. (2015).

Anonymous. (2015). Annual agricultural statistics. . Retrieved from http://www.koaj.ir ( in persian). Béné, C. (2013). Towards a quantifiable measure of resilience. IDS Working Papers, 2013(434), 1-27.

Briguglio, L., Cordina, G., Farrugia, N., \& Vella, S. (2006). Conceptualizing and measuring economic resilience. Building the Economic Resilience of Small States, Malta: Islands and Small States Institute of the University of Malta and London: Commonwealth Secretariat, 265-288. 
Chaves, H. M., \& Alipaz, S. (2007). An integrated indicator based on basin hydrology, environment, life, and policy: the watershed sustainability index. Water Resources Management, 21(5), 883-895.

Darnhofer, I. (2014). Resilience and why it matters for farm management. European Review of Agricultural Economics, 41(3), 461-484.

Fiksel, J. (2006). Sustainability and resilience: toward a systems approach. Sustainability: Science, Practice, \& Policy, 2(2).

Food, U., \& Administration, D. (2009). Grade "A"pasteurized milk ordinance. US Food and Drug Administration, Washington, $D C, 52$.

Galal, N. M., \& Moneim, A. F. A. (2015). A mathematical programming approach to the optimal sustainable product mix for the process industry. Sustainability, 7(10), 13085-13103.

Glover, J. (2012). Rural resilience through continued learning and innovation. Local Economy, 27(4), 355-372.

Iqbal, S. Z., Jinap, S., Pirouz, A., \& Faizal, A. A. (2015). Aflatoxin M 1 in milk and dairy products, occurrence and recent challenges: A review. Trends in Food Science \& Technology, 46(1), 110-119.

Morgan, N. A., \& Piercy, N. F. (1998). Interactions between marketing and quality at the SBU level: influences and outcomes. Journal of the Academy of Marketing Science, 26(3), 190-208.

Nádia, M., Diane, S., Débora, O., \& Mirlei, R. E. (2012). Evaluation of Microbiological quality of Raw Milk produced at two properties in the Far West of Santa Catarina, Brasil. Food and Public Health, 2(3), 79-84.

Naylor, R. L. (2009). Managing food production systems for resilience Principles of Ecosystem Stewardship (pp. 259-280): Springer.

Park, C.-H., \& Irwin, S. H. (2004). The profitability of technical analysis: A review.

Qobadi. M, M. D., Shahrami. A. (2015). Evaluation of Energy Indi ces in Qazvin Dairy Farms using Data Envelopment Analysis. Biomedical Engineering Journal, 4(4), 16.

Rose, A. (2015). Measuring Economic Resilience: Recent Advances and Future Priorities.

Schukken, Y. H., Wilson, D. J., Welcome, F., Garrison-Tikofsky, L., \& Gonzalez, R. N. (2003). Monitoring udder health and milk quality using somatic cell counts. Veterinary research, 34(5), 579-596.

Sysak, T. S. (2013). Drought, power and change: using Bourdieu to explore resilience and networks in two northern Victoria farming communities: University of Melbourne, Department of Resource Management and Geography.

van Apeldoorn, D., Kok, K., Sonneveld, M., \& Veldkamp, T. (2011). Panarchy rules: rethinking resilience of agroecosystems, evidence from Dutch dairy-farming. Ecology and Society, 16(1).

Von Mises, L. (2008). Profit and loss: Ludwig von Mises Institute.

Wallace, R. L. (2009). Bacteria counts in raw milk. Dairy Cattle. Management, 1-4.

www.fao.org.

Table 1 economic resilience indicator criteria in dairy farms

\begin{tabular}{l|l}
\hline Sub-indicator of economic resilience indicator & Criteria description \\
\hline & a-Somatic Cell Count (SCC) in milk \\
Quality factors in milk production & b-Microbial load in milk \\
& c-Aflatoxin in milk \\
& d-Antibiotics in milk \\
\hline Profitability & Total cost divided by total revenue \\
\hline
\end{tabular}


Table 2 Result of quality factors and profitability Indicators of Dairy Farms

\begin{tabular}{|c|c|c|c|c|c|c|c|}
\hline indicator & Amount & Unit & SCC & Microbial load & Aflatoxin & Antibiotic & Profitability \\
\hline Quality & & & \multirow{8}{*}{0.42} & \multirow{8}{*}{0.48} & \multirow{8}{*}{0.17} & \multirow{8}{*}{0.98} & \multirow{8}{*}{0.46} \\
\hline SCC & 269500 & cell $/ \mathrm{ml}$ & & & & & \\
\hline Microbial load & 283000 & $\mathrm{CFU} / \mathrm{ml}$ & & & & & \\
\hline Aflatoxin & 224 & $\mathrm{Ppb}$ & & & & & \\
\hline Antibiotic & 15 & $\mathrm{Mg} / \mathrm{ml}$ & & & & & \\
\hline \multicolumn{3}{|l|}{ Profitability } & & & & & \\
\hline Total Cost & $2 \times 10^{09}$ & IRR/day & & & & & \\
\hline Total Revenue & $5.2 \times 10^{09}$ & IRR/day & & & & & \\
\hline
\end{tabular}

Table 3 Determine Economic Resilience Indicator Levels of Dairy Farms in this study

\begin{tabular}{l|c}
\hline Economic Resilience Level & Economic Resilience Indicator (ERI) \\
\hline Low & $E R I<0.6$ \\
\hline Middle & $0.6 \leq E R I \leq 0.8$ \\
\hline High & $E R I>0.8$
\end{tabular}

